\title{
A Review of Literature on Punarnavadi Mandura: An Ayurvedic Herbo-Mineral Preparation
}

\author{
Janmejaya Samal ${ }^{1 *}$ and Ranjit Kumar Dehury ${ }^{2}$ \\ 'Research Consultant, International Union against Tuberculosis and Lung Disease (The union), Pune, Maharashtra, INDIA. \\ 2Department of Healthcare Management, Faculty, Healthcare Management, Goa Institute of Management, Panaji, Goa, INDIA.
}

\begin{abstract}
Background: Punarnavadi Mandura is an Ayurvedic herbo-mineral preparation primarily used as an anemia correcting agent while its role in other clinical conditions has also been studied. Objective: To understand the role of Punarnavadi Mandura in controlling anemia and other clinical conditions and its pharmacognostical and phytochemical properties. Methodology: A search of literature was carried out using "Punarnavadi Mandura" as the only key word and a total of 33 literatures were obtained of which 5 titles were finally selected for the review. Results and Discussion: Of the 5 studies identified 3 studies focused on the role of Punarnavadi Mandura as an anemia correcting agent, one study identified its role in other clinical condition (Diabetic Nephropathy), one study focused on the pharmacognostical and phytochemical analysis while one study focused on both the analysis of pharmacognostical and phytochemical properties and its role as an anemia correcting agent. As per these studies Punarnavadi Mandura is an effective remedy for iron deficiency anemia (IDA) of all ages. Statistically significant result has been obtained in subjective and hematological parameters. Furthermore its role in other clinical conditions has also been
\end{abstract}

found effective, especially in Diabetic Nephropathy (DN), as a Naimithika Rasayana. Punarnavadi Mandura is currently a part of National health programme and is included in ASHA drugs kit for the management of IDA at community level. Conclusion: Given the efficacy of Punarnavadi Mandura in IDA, at all ages, its usage should be fostered more in Indian communities especially the rural communities where IDA is endemic.

Key words: Anti-anemic, Naimithika Rasayana, Pharmacognostical, Phytochemical, Iron Deficiency Anemia, ASHA drugs kit.

\section{Correspondence:}

Dr Janmejaya Samal,

C/O-Mr Bijaya Ketan Samal, At-Pansapalli, Po-Bangarada, Via-Gangapur, Dist-Ganjam, PIN-761123,

Odisha, INDIA.

Email: janmejayasamal@yahoo.com

DOI : $10.5530 /$ pj.2016.3.2

\section{INTRODUCTION}

Punarnavadi Mandura is an Ayurvedic herbo-mineral preparation primarily used as an anemia correcting agent while its role in other clinical conditions has also been studied. The role of Punarnavadi Mandura as an anemia correcting agent has been studied by different authorities in India. ${ }^{1-4}$ The classical description of Punarnavadi Mandura is found in one of the major classics of Ayurveda, Charak Samhita. Acharya Charak has described the role of Punarnavadi Mandura as an anemia correcting agent in his classical treatise, Charak Samaita, in Chikitsa Stana. ${ }^{5}$ The ingredients described in Charak Samhita for the preparation of Punarnavadi Mandura have been delineated in Table 1. Furthermore a brief description of the preparation of Punarnavadi Mandura is described in Table 2. Punarnavadi Mandura act as an anemia correcting agent possibly by its effect on Srotosa (micro channels) and Agni (digestive fire mechanism) and thereby enhancing digestive capacity owing to Deepana (appetizer), Pachana (digestive) properties. ${ }^{6}$ In addition to anemia its role in other clinical conditions has been studied as well ${ }^{7}$ Punarnavadi Mandura is being used for many other clinical conditions which include malabsorption syndrome, inflammation, splenic disease, intermittent fever, haemorrhoids, diseases of skin, and helminthiasis/ worm infestation. ${ }^{5,8}$ Furthermore Punarnavadi Mandura is currently a part of national health programme in India. It has been included in the ASHA drugs kit for the management of iron deficiency anemia (IDA) at community level in India. This drug has been included with the initiation of National Rural Health Mission (NRHM) in India under the aegis of "Mainstreaming of AYUSH and Revitalization of Local health Traditions" in India. ${ }^{9,10}$ With this background a review was carried out in order to understand the role of Punarnavadi Mandura in anemia and other pathological conditions.

\section{OBJECTIVE}

The main objective of this literature review is;

- To understand the role of Punarnavadi Mandura as an anemia correcting agent,

- To understand the role of Punarnavadi Mandura in other clinical conditions and

- To understand the pharmacognostical and phytochemical properties of Punarnavadi Mandura.

\section{METHODOLOGY}

A manual search strategy was adopted to obtain research papers on Punarnavadi Mandura. The search was primarily carried out using PUBMED and Google Scholar search engines and the only key word used for the purpose of search was "Punarnavadi Mandura" and was done deliberately in order to obtain research papers particularly on Punarnavadi Mandura only. A total of 33 articles were obtained by the end of this search process and 5 full texts articles were finally selected for the purpose of this review. Figure 1, shows the flowchart of selection of articles for the purpose of this review.

\section{Inclusion and exclusion criteria}

Articles published in English language only were included in the review. Furthermore original researches were only recruited for the purpose of review which precludes review articles and theoretical research. The studies those did not fall in these categories were excluded from review. 


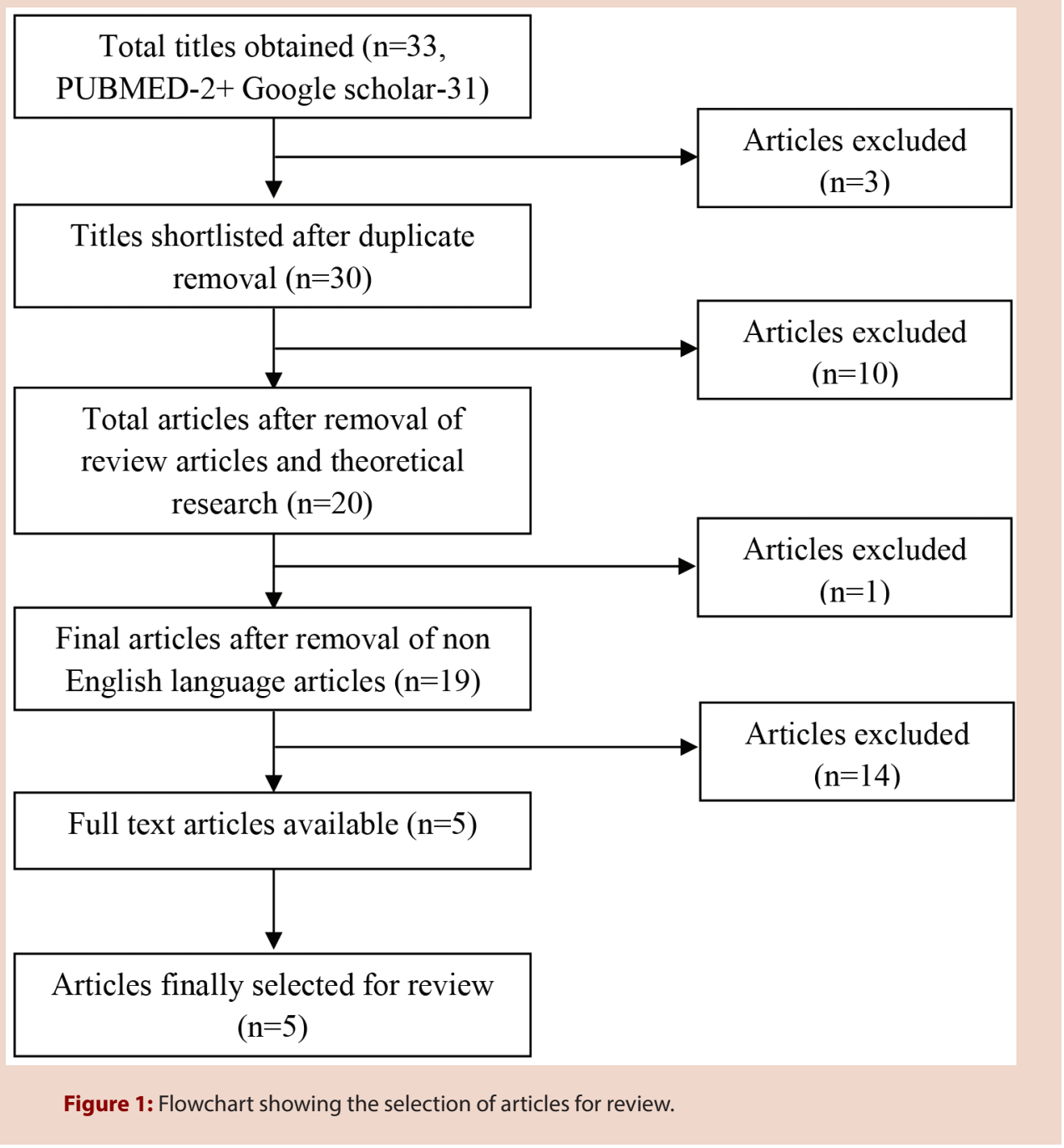

\section{RESULTS}

Of the 5 studies identified 3 studies $(n=5)$ focused on the role of Punarnavadi Mandura as an anemia correcting agent (Table 3), 1 study $(n=5)$ identified its role in other clinical condition (Table 4), 1 study $(n=5)$ focused on the pharmacognostical and phytochemical analysis while 1 study $(n=5)$ focused on both the analysis of pharmacognostical and phytochemical properties (Table 2 ) and its role as an anemia correcting agent.

\section{DISCUSSION}

Punarnavadi Mandura is an effective herbo-mineral preparation for the management of Iron deficiency anemia (IDA). Furthermore it was observed that this drug is effective in IDA among all age groups; pediatric, geriatrics and adult age groups. ${ }^{6,12,13}$ Studies also reveal that this drug is well tolerated among the patients without any side effects and untoward effects compared to allopathic drug in one of the clinical trials. ${ }^{12}$ One of the advantages of Ayurvedic preparations is that most of these drugs are administered with some vehicle which improves the efficacy of the parent drug and Punarnavadi Mandura is not an exception to this principle. Punarnavadi Mandura is preferably administered with butter milk which is acidic $\mathrm{pH}$ and contains lactic acid. Iron absorption is aided by decreased $\mathrm{pH} .{ }^{14}$ Furthermore it may also possible that iron combines with lactic acid to form ferrous lactate before absorp- tion. Modern medical system uses ferrous lactate for the management of Iron deficiency anemia. ${ }^{15}$ Alternatively it may also happen that the proteins of butter milk or the amino acids released after digestion may combine with iron before the absorption takes place. This point of view is also supported by the World Health Organization as it supports the use of meat and other proteins for the absorption of iron. ${ }^{16}$ However, Ayurveda has a different view on the role of Punarnavadi Mandura in controlling anemia which is primarily directed towards Agni (Digestive fire) ${ }^{6}$ But this concept is also indirectly related to the mechanism of absorption of iron in the gastro-intestinal tract by the process of Deepana and Pachana. ${ }^{6,17}$

The study that focused on geriatric anemia has offered a probable explanation of the action of Punarnavadi Mandura among geriatric patients suffering from anemia. Triphala, Trikatu, Chitraka, Vidanga and Pippalimula have appetizer, digestive and carminative properties which improves digestive power and ultimately absorption of the drug. The components like Trivrita, Haritaki and Danti act as laxative which help in relieving constipation mainly found in old age. Haridra, Amalaki, Pippali, Punarnava and Trivrita were mentioned as Panduhara (antianemic) by various Acharyas. Amalaki, Danti, Pippali, Punarnava, Kushtha and Daruharidra are documented as drugs which are having immunomodulator and antioxidant properties having the potential of providing beneficial health effects in geriatric anemia. ${ }^{6}$ 
Table 1: Composition of Punarnavadi Mandura

\begin{tabular}{|c|c|c|c|}
\hline Ingredients & Latin name & Parts used & Proportion \\
\hline Punarnava & Boerhaavia diffusa Linn. & Root & 1 part \\
\hline Trivrita & Operculina turpethum Linn. & Root & 1 part \\
\hline Shunthi & Zingiber officinale Rosc. & Rhizome & 1 part \\
\hline Maricha & Piper nigrum Linn. & Fruit & 1 part \\
\hline Pippali & Piper longum Linn. & Fruit & 2 parts \\
\hline Vidanga & Embalia robusta C. B. Clarke & Fruit & 1 part \\
\hline Devdaru & Cedrus deodara (Roxb.) & Wood & 1 part \\
\hline Kushtha & Saussurea lappa C.B. Clarke & Root & 1 part \\
\hline Haridra & Curcuma longa Linn. & Rhizome & 1 part \\
\hline Daruharidra & Berberis aristata DC. & Root & 1 part \\
\hline Amalaki & Embalica officinalis Gaertn. & Fruit & 1 part \\
\hline Bibhitaki & Terminalia bellirica Roxb. & Fruit & 1 part \\
\hline Haritakai & Terminalia chebula Retz. & Fruit & 1 part \\
\hline Danti & Baliospermum montanum (Willd.) & Root & 1 part \\
\hline Chavya & Piper chaba Hunter. & Root & 1 part \\
\hline Indrayava & Holarrhena antidysenterica (Roxb. ex Flem.) Wall. & Seed & 1 part \\
\hline Pippalimula & Root of Piper longum Linn. & Root & 1 part \\
\hline Musta & Cyperus rotundus Linn. & Rhizome & 1 part \\
\hline Chitraka & Plumbago zeylanica Linn. & Root & 1 part \\
\hline Mandura Bhasma & Incinerated red oxide of iron $\left(\mathrm{Fe}_{2} \mathrm{O}_{3} \mathrm{H}_{2} \mathrm{O}\right)$ & & 40 parts \\
\hline Gomutra & Cow's urine & & Q.S. \\
\hline
\end{tabular}

Table 2: Pharmacognostical and Phytochemical analysis of Punarnavadi Mandura

\begin{tabular}{|c|c|c|c|c|}
\hline Author & Journal and YOP & Study Type & Methodology & Major outcomes \\
\hline $\begin{array}{l}\text { Kori, V. K., Patel, K. } \\
\text { S., Shukla, V. J., and } \\
\text { Harisha, C. R }{ }^{11}\end{array}$ & $\begin{array}{l}\text { Int. J Res. Ayurveda } \\
\text { Pharm. 2012; } \\
\text { 3(2):215-221. }\end{array}$ & $\begin{array}{l}\text { Laboratory } \\
\text { Investigation }\end{array}$ & $\begin{array}{l}\text { Punarnavadi Mandura vati was prepared } \\
\text { by the following process and its } \\
\text { phramacognostical and pytochemical analysis } \\
\text { was carried out. The ingredients mentioned } \\
\text { in Table 1, were cleaned, dried, powdered } \\
\text { and passed through sieve number } 85 . \\
\text { Mandura bhasma was mixed with cow urine } \\
\text { and heated. } 5 \% \text { of gum acacia was mixed as } \\
\text { binding agent. The mixture was converted in } \\
\text { to granules and then punched in to } 500 \mathrm{mg} \\
\text { tablets by tablet making machine. }\end{array}$ & $\begin{array}{c}\text { The organoleptic assessment shows that } \\
\text { Punarnavadi Mandura vati is light reddish } \\
\text { brown in color, gomutra gandhi (smells like } \\
\text { cow urine), Astringent-bitter in taste and solid } \\
\text { in consistency with rough surface. } \\
\text { Physiochemical parameters-water soluble } \\
\text { extract and methanol soluble extract were } \\
\text { found to be } 13.09 \% \mathrm{w} / \mathrm{w} \text { and } 6.37 \% \mathrm{w} / \mathrm{w} \\
\text { respectively. }\end{array}$ \\
\hline $\begin{array}{c}\text { Sharma DC, } \\
\text { Chandiramani D, } \\
\text { Riyat M, Sharma P. }{ }^{12}\end{array}$ & $\begin{array}{c}\text { Indian Journal } \\
\text { of Clinical } \\
\text { Biochemistry. 2007; } \\
22(2): 123-8 .\end{array}$ & $\begin{array}{l}\text { Laboratory } \\
\text { Investigation }\end{array}$ & $\begin{array}{l}\text { The powdered drug was first ashed in a muffle } \\
\text { furnace and the residue was digested in aqua- } \\
\text { regia. The volume of the extract was reduced } \\
\text { by boiling and then diluted by deionised } \\
\text { water. The minerals-iron, copper, zinc, } \\
\text { calcium and magnesium were determined } \\
\text { by atomic absorption spectrophotometry, } \\
\text { while sodium and potassium were in flame } \\
\text { photometer. The analysis of carbon, hydrogen } \\
\text { and nitrogen was done by RSIC of Central } \\
\text { Drug Research Institute, Lucknow. }\end{array}$ & $\begin{array}{l}\text { The percentage distribution of elemental } \\
\text { composition of Punarnavadi Mandura is as } \\
\text { follows; Carbon- } 23.61 \% \text {, Hydrogen-3.02\%, } \\
\text { Nitrogen-1.44\%, Iron-20.00\%, Copper- } \\
0.01 \% \text {,Z inc- } 0.01 \% \text {, Calcium-3.81\%, } \\
\text { Magnesium- } 1.03 \% \text {, Sodium- } 0.50 \% \text {, } \\
\text { Pottasium- } 1.25 \% \text {, Total- } 54.68 \% \text {, Other } \\
\text { elements such as Oxygen, Sulphur etc.- } 45.32\end{array}$ \\
\hline
\end{tabular}

${ }^{\star}$ RSIC-Regional Sophisticated Instrumentation Centre. 


\section{Table 3: Studies showing the role of Punarnavadi Mandura as an Anemia correcting formulation}

\begin{tabular}{|c|c|c|c|c|}
\hline Author & Journal and YOP & Study Type & Methodology & Major outcomes \\
\hline $\begin{array}{l}\text { Sharma DC, } \\
\text { Chandiramani D, Riyat } \\
\text { M, Sharma P. }{ }^{12}\end{array}$ & $\begin{array}{l}\text { Indian Journal } \\
\text { of Clinical } \\
\text { Biochemistry. 2007; } \\
22(2): 123-8 .\end{array}$ & $\begin{array}{c}\text { Clinical trial } \\
\text { conducted at } \\
\text { hospital setting }\end{array}$ & $\begin{array}{l}20 \text { patients ( } 8 \text { male }+12 \text { female) were } \\
\text { administered with } 125 \mathrm{mg} \text { of Punarnavadi } \\
\text { Mandura (containing } 100 \mathrm{mg} \text { of elemental } \\
\text { iron) for } 30 \text { days who were undergoing } \\
\text { treatment for moderate to severe anemia by } \\
\text { Ayurvedic Physicians. Each patient was given } \\
125 \mathrm{mg} \text { twice daily with buttermilk or water } \\
\text { thus consuming } 500 \mathrm{mg} \text { of this tablet per day. }\end{array}$ & $\begin{array}{l}\text { The initial } \mathrm{Hb} \text { gm } \% \text { among the patients } \\
\text { ranged between } 3.2 \text { to } 9.8 \text { with a mean of } \\
7.50 \text { gm } \% \\
\text { The percentage changes in hematological } \\
\text { and iron parameters after treatment are as } \\
\text { follows; } \\
\text { Hb- } 48.0 \% \text {, PCV-23.1\%, TRBC- } 15.0 \% \text {, } \\
\text { MCV-7.5\%, MCHC-20.7\%, MCH-30.3\%, } \\
\text { PI- } 53.5 \% \text {, TIBC-(-8.7\%), PS- } 68.0 \% \text { and } \\
\text { FER- } 14.9 \% \text {. } \\
\text { The Hb regeneration per day for } \\
\text { Punarnavadi Mandura was } 0.12 .\end{array}$ \\
\hline Pandya $\mathrm{MG}$, Dave $\mathrm{AR}^{6}$ & Ayu 2014;35:252-60 & $\begin{array}{c}\text { Hospital based } \\
\text { clinical trial }\end{array}$ & $\begin{array}{l}50 \text { clinically diagnosed geriatric anemia cases } \\
\text { were administered with } 500 \mathrm{mg} \text { of Punarnadi } \\
\text { Mandura in two equally divided doses post } \\
\text { lunch and dinner with butter milk for } 90 \text { days. }\end{array}$ & $\begin{array}{c}\text { Statistically significant results were } \\
\text { obtained in all chief complaints such as } \\
\text { Aruchi (95.38\%), Daurbalya ( } 94.59 \%), \\
\text { Pindikodwestana ( } 93.46 \%), \text { Jwara (80\%) } \\
\text { and Bhrama (82.43\%) except in Akshikuta } \\
\text { Shotha (29.63\%) however hematological } \\
\text { parameters were not statistically } \\
\text { significant. }\end{array}$ \\
\hline Das A, Saritha S. ${ }^{13}$ & $\begin{array}{l}\text { Ancient Science } \\
\text { of Life. } 2013 \text { Jan; } \\
\text { 32(Suppl 2):S86. }\end{array}$ & $\begin{array}{l}\text { Clinical Trail } \\
\text { conducted at } \\
\text { hospital setting }\end{array}$ & $\begin{array}{l}50 \text { children of } 10 \text { to } 14 \text { years of age were } \\
\text { administered with } 500 \mathrm{mg} \text { of Punarnavadi } \\
\text { Mandura and } 10 \mathrm{ml} \text { of Dadimadi Grita twice } \\
\text { daily with luke warm water for } 84 \text { days. }\end{array}$ & $\begin{array}{l}\text { Statistically significant }(\mathrm{P}<0.001) \text { results } \\
\text { were obtained after the administration } \\
\text { of these two drugs among these children } \\
\text { with IDA. Furthermore significant results } \\
\text { were obtained in hemoglobin and other } \\
\text { hematological parameters like MCHC, } \\
\text { MCV, PCV, Reticulocyte Count, periphera } \\
\text { Blood smear, serum iron, serum Ferritin } \\
\text { and Total Iron Bindinig Capacity in the } \\
\text { treatment Group }(\mathrm{P}<0.001) \text {. }\end{array}$ \\
\hline
\end{tabular}

${ }^{*}$ IDA: Iron Deficiency Anemia, TRBC: Total red blood cell, MCV: Mean corpuscular volume, MCH: Mean corpuscular hemoglobin, MCHC: Mean corpuscular hemoglobin concentration, PCV: Packed cell volume, TIBC: Total iron binding capacity, Hb: Hemoglobin, FER: Plasma Ferritin, PS: Percent Saturation.

Table 4: Studies showing the role of Punarnavadi Mandura in other clinical conditions

\begin{tabular}{|c|c|c|c|c|}
\hline Author & Journal and YOP & Study Type & Methodology & Major outcomes \\
\hline $\begin{array}{c}\text { Akarshini AM, } \\
\text { Aruna }^{7}\end{array}$ & Ayu 2014;35:378-83 & $\begin{array}{l}\text { Hospital based } \\
\text { clinical trial }\end{array}$ & $\begin{array}{l}15 \text { patients of either sex with Diabetic } \\
\text { Nephopathy, aged between } 20 \text { and } 80 \text { years, were } \\
\text { administered with a compound preparation } \\
\text { containing Shilajatvadi Vataka- } 6 \text { g twice daily in } \\
\text { empty stomach with } 100 \mathrm{ml} \text { of milk, Punarnavadi } \\
\text { Mandura- } 2 \text { g, } 3 \text { times a day after food, Pippali } \\
\text { Mooladi Paneeya- along with Amrita and } \\
\text { Bringaraja-30 ml, twice a day, before food, } \\
\text { Triphala Guggulu- } 3 \text { g, twice a day, after food for } \\
48 \text { days. }\end{array}$ & $\begin{array}{l}\text { There was symptomatic improvement in Pada } \\
\text { Shotha (pedal edema), Akshikoota Shotha } \\
\text { (retroorbital edema). Statistically significant } \\
\text { improvement was observed in Agni (gastric fire) } \\
\text { status. Significant improvement was observed in } \\
\text { micro-albuminuria in which the difference of pre } \\
\text { and post test mean of } 83.76 \mu \mathrm{g} / 24 \mathrm{~h} \text { was observed }\end{array}$ \\
\hline
\end{tabular}

Amalaki is a rich dietary source of Vitamin C, a powerful water-soluble antioxidant, helps in increasing iron absorption from the gut. ${ }^{18}$ One of the studies on Pippali suggests that, piperine gets absorbed very quickly across the intestinal barrier through the intracellular pathway. It may modulate membrane dynamics owing to its easy partitioning properties thus helping in efficient permeability across the barriers. In addition Pippali is said to be bio-availability enhancer of drug, further helping in easy assimilation of the drug components. ${ }^{19}$

Mandura Bhasma (incinerated form of iron- $-\mathrm{Fe}_{2} \mathrm{O}_{3}$ ), by virtue of Rasa and Guna, pacifies aggravated Pitta and maintains the normalcy thereby improving the digestion and metabolism. The ferric and ferrous fractions of Mandura provide sufficient iron needed for normal erythropoiesis. ${ }^{20}$ Furthermore the presence of erythropoietin hormone in cow urine helps in the improvement of anemia. ${ }^{21}$
In addition to the anti-anemic properties of Punarnavadi Mandura, it is also found effective in other clinical conditions, such as Diabetic nephropathy, as reported by one of the studies. ${ }^{7}$ The study reported that the combination of Shilajatvadi Vataka, Punarnavadi Mandura, Pippali Mooladi Paneeya-along with Amrita and Bringaraja and Triphala Guggulu acted as a Naimithika Rasayana and helped in managing Diabetic nephropathy. ${ }^{7}$ Naimithika Rasayana is a unique concept described in Ayurveda which promotes vigor and vitality and instills the ability to hold out disastrous outcomes of diseases. .22,23 $^{2}$

\section{CONCLUSION}

As per different studies Punarnavadi Mandura is effective against Iron deficiency anemia at all ages. Studies also reveal that it is well tolerated among patients without any side effects and untoward health effects 
hence the same can effectively be used for IDA. Moreover Punarnavadi Mandura is also more efficacious compared to allopathic hematinics as per one of the studies. The use of this drug under national health programme in India also proves its efficacy in managing the IDA at community level especially in rural India. Hence this drug can be effectively used in rural India where the prevalence IDA is rampant.

\section{ACKNOWLEDGEMENT}

None.

\section{CONFLICT OF INTEREST}

None Declared.

\section{REFERENCES}

1. Shantharam KS, Gopinath BG, Mangalgi SG. Management of Pandu roga associated with Shotha, M.D. Thesis. Mysore: Kayachikitsa Department, Gov. Ayurvedic Medical College RUGHS. 1986.

2. Sengupta S, Panda N, Mahapatra SK. A clinical study on Pandu associated with Ankushmukhi krimi-Ankylostoma duodenale and its management by punarnavad manduram, M.D. Thesis. Puri: Dept. of Kayachikitsa, Gopalbandhu Ayurveda Mahavidhalaya; 1996.

3. Bombarde DT. Effect of Punarnavadi Mandura in Pandu Roga, M.D. Thesis Bombay: Dept. of Kayachikitsa, R.A. Podar Medical College (Ayu); 1987.

4. Vasundhara S, Tiwari PV. Treatment of garbhini pandu with punarnava mandoora. M.D. Thesis. Varanasi: Dept. of Prasuti-Balaroga, Faculty of Ayurveda. Institute of Medical Science BHU. 1980.

5. Agnivesha, Charaka, Dridhabala, Charaka Samhita, Chikitsa Sthana, Panduroga chikitsa Adhyaya, 16/93-96, edited by Vaidya Jadavji Tirkamji Acharya, $2^{\text {nd }}$ ed. Chaukhamba Surbharati Prakashana Varanasi. 2005;530.

6. Pandya MG, Dave AR. A clinical study of Punarnava Mandura in the management of Pandu Roga in old age (geriatric anemia). Ayu. 2014; 35(3):252-60.

7. Akarshini AM, Aruna. Management of Madhumeha Janya Upadrava with special reference to diabetic nephropathy-A clinical study. Ayu. 2014;35(4):378-83.

8. Mishra S, Aeri V, Gaur PK, Jachak SM. Phytochemical, Therapeutic, and Ethnopharmacological Overview for a Traditionally Important Herb: Boerhavia diffusa
Linn. Bio Med Research International. 2014 May 14;2014.

9. Samal J. Role of AYUSH workforce, therapeutics, and principles in health care delivery with special reference to National Rural Health Mission. Ayu. 2015;36(1):5-8.

10. Samal J. The Concept of Public Health in Ayurveda. International Ayurvedic Medical Journal. 2013;1(2):1-5

11. Kori VK, Patel KS, Shukla VJ, Harisha CR. Pharmacognostical and phyto-chemical evaluation of Punarnavadi Mandura: An effective formulation for iron deficiency anemia. International Journal of Research in Ayurveda and Pharmacy. 2012;3(2):215-21.

12. Sharma DC, Chandiramani D, Riyat M, Sharma P. Scientific evaluation of some Ayurvedic preparations for correction of iron deficiency and anemia. Indian Journal of Clinical Biochemistry. 2007;22(2):123-8.

13. Das A, Saritha S. PA03. 17. A clinical evaluation of Punarnavadi Mandura and Dadimadi Ghritha in management of pandu (Iron defeciency anaemia). Ancient Science of Life. 2013;32(Suppl 2):S86.

14. Sharma DC, Mathur R, Singh PP. Iron metabolism. A Review. Ind J Clin Biochem. 1993:8(2):80-101.

15. Singhal M. Iron Formulations 2001; Drug Index 4:325-30.

16. Sood SK. Epidemiology of Iron Deficiency Anemia MEDIWAVE. 1995;1:12-7.

17. Sushruta, Sushruta Samhita, Sutrasthana, Dravadravya Vidhi Adhyaya, 45/54 Edited by Kaviraj Ambikadatta Shastri, reprint ed. Chaukhambha Sanskrit Sansthan, Varanasi, 2005; 176

18. Mohan H. Text Book of Pathology. $5^{\text {th }}$ ed. New Delhi: Jaypee Brothers, Medical Publishers; 2005. pp. 369

19. Shoba G, Joy D, Joseph T, Majeed M, Rajendran R, Srinivas PS. Influence of piperine on the pharmacokinetics of curcumin in animals and human volunteers. Planta Med. 1998;64(4):353-6.

20. Baghel MS, Prajapati PK, Ravishankar B, Patgiri BJ, Shukla VJ, Galib. Monograph on Punarnava Mandura (SMP and Safety Profile). Jamnagar: India, Institute for Post Graduate Teaching and Research in Ayurveda. Gujarat Ayurved University. 2009; pp

21. Available from: http://www.goshala.com/Articles/2011/Jun/Urinebenefits. [Last accessed on 2016 Jan 03]

22. Samal J. Ayurvedic management of Pulmonary Tuberculosis (PTB): A systematic review. J Intercult Ethnopharmacol, [cited January 04, 2016]; Online First: 13 Nov, 2015. doi:10.5455/jice.20151107020621

23. Singh RH. Rasayana, Vajikarana (promotive therapy). In: Sharma PV, editor History of Medicine in India. New Delhi, India. Indian National Science Academy. 1992.p.242-54.
PICTORIAL ABSTRACT

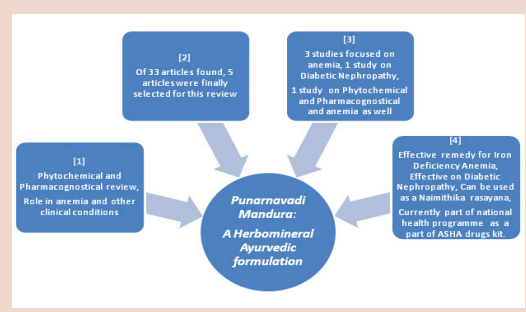

\section{SUMMARY}

- PunarnavadiMandura (PM) is effective against Iron Deficiency Anemia (IDA)

- Statistically significant results were observed in subjective and hematological parameters for IDA.

- PMis effective in other clinical conditions as well; Diabetic Nephropathy (DN).

- PM can be used as a NaimithikaRasayana in combination with other drugs.

- PM is currently part of National health programme in India as a part of ASHA (Accredited Social Health Activist) drugs kit.

\section{ABOUT AUTHORS}

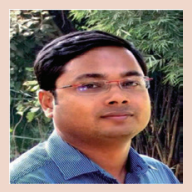

Janmejaya Samal: Is a public health professional having studied both health and social sciences. He holds a BAMS degree from Sambalpur University, Odisha; MPH from Rajiv Gandhi University of Health Sciences, Bengaluru and an MA in International Family Studies from Tata Institute of Social Sciences, Mumbai. His areas of interest include health systems and policy, social and behavioral health and interdisciplinary research in AYUSH and Public health.

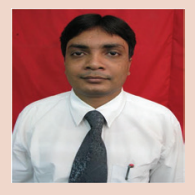

Ranjit Kumar Dehury: Is a faculty member at Goa Institute of Management, Panaji, Goa, India and is a Doctoral fellow under the Department of Humanities and Social Sciences, Indian Institute of Technology Kharagpur, India. He has obtained his Master's degree in Hospital Management from Tata Institute of Social Sciences, Mumbai. His Areas of interest are Human Resources for Health, Health Systems Studies, Maternal Health, Hospital administration and Traditional and Complementary Medicine. He has worked as a hospital consultant with NRHM, Chhattisgarh and NRHM, Odisha. 